\title{
Pengembangan Buku Ajar Keterampilan Dasar Mengajar Berbasis Sains Teknologi Masyarakat pada Program Studi Pendidikan Biologi IKIP Budi Utomo Malang
}

\author{
As'ad Syamsul Arifin \\ Program Studi Pendidikan Biologi IKIP Budi Utomo Malang \\ Jalan Citandui 46 Malang \\ Email: asad.ilem@yahoo.com \\ Trio Ageng Prayitno \\ Program Studi Pendidikan Biologi IKIP Budi Utomo Malang \\ Jalan Citandui 46 Malang
}

\begin{abstract}
The Basic Process of Learning Biology Lecture Course Biology Education Budi Utomo IKIP Malang expected to facilitate the prospective teachers who have professional competence and pedagogy. The process of course are done not much use of learning resources that can stimulate students in order to be sensitive to the problems in society and are able to integrate between science by technological development. Thus, a new innovation that is required one of which develop teaching materials science technology-based society. Learning materials developed only limited subject matter skills open and close the lesson of biology. Teaching material development model of open and closed development model is a biology lesson Thiagarajan 1974: consists of define, design, develop, and disseminate (special stage is not yet implemented). Technology community science was declared valid. In conclusion, the material taught on the subject of open and close skills lessons of biology-based technology the community science was developed can be used in the process of learning basic biology lectures.
\end{abstract}

Keywords: learning resources, material, thiagarajan development

Mulyasa (2009:69) Pembelajaran merupakan suatu proses yang kompleks dan melibatkan berbagai aspek yang saling berkaitan. Oleh karena itu, untuk merubah pembelajaran yang kompleks tersebut menjadi kreatif, dan menyenangkan, diperlukan berbagai keterampilan membelajarkan atau keterampilan mengajar yang dilaksanakan oleh pendidik. IKIP Budi Utomo adalah salah satu Perguruan Tinggi Swasta yang berbasis Kependidikan dan Keguruan yang terdapat di kota Malang. Pendidikan biologi adalah salah satu Program Studi yang ada di IKIP Budi Utomo memiliki tujuan menghasilkan lulusan S1 pendidikan biologi yang memiliki kompetensi di bidang pendidikan dankompetensibidang pengetahuan biologi. Mahasiswa Program Studi Pendidikan Biologi IKIP Budi Utomo dituntut untuk mengikuti beberapa kelompok matakuliah agar mendapatkan gelar S1 Pendidikan Biologi (Katalog IKIP Budi Utomo, 2010).
Menurut Kurikulum Program Studi Pendidikan Biologi FPIEK (2009), Dasar Proses Pembelajaran Biologi adalah salah satu matakuliah yang termasuk dalam kelompok Matakuliah Keilmuan dan Keterampilan (MKK). Matakuliah Dasar Proses Pembelajaran Biologi adalah mata kuliah wajib yang tidak boleh ditinggalkan oleh mahasiswa. Matakuliah Dasar Proses Pembelajaran Biologi bertujuan untuk membekali keterampilan dasar proses belajar mengajar biologi sesuai dengan karakteristik peserta didik dan perkembangan pembelajaran biologi masa kini, serta keterampilan menciptakan pembelajaran biologi inovatif dan menyenangkan (SAP Matakuliah Dasar Proses Pembelajaran Biologi).

Lulusan Program Studi Pendidikan Biologi IKIP Budi Utomo dituntut menjadi guru biologi tingkat Pendidikan Dasar, Menengah, dan Atas yang berkompetensi pedagogik, kepribadian, sosial, dan profesional (Katalog IKIP Budi 
Utomo, 2010). Kompetensi pedagogik dan profesional harus dikuasai oleh mahasiswa IKIP Budi Utomo sebagai bekal menjadi pendidik di sekolah. Hal tersebut didasarkan atas tuntutan bahwa seorang guru harus mampu memahami karakteristik peserta didik, mengembangkan kurikulum,membuatperencanaanpembelajaran, melaksanakan kegiatan pembelajaran, mengevaluasi hasil belajar peserta didik, dan memanfaatkan teknologi dalam pembelajaran.

Pentingnya matakuliah Dasar Proses Pembelajaran Hasil observasi peneliti pada perkuliahan matakuliah Dasar Proses Pembelajaran Biologipadabulan April 2013 menemukan bahwa mahsiswa kurang percaya diri saat melakukan demostrasi mengajar (microteaching), kurang bisa memacu motivasi peserta microteaching untuk fokus pada materi yang akan dibahas karena calon pendidik tidak bisa mengkaitkan antara fenomena alam sekitar dengan konsep yang akan dipelajari, kurang bisa berkomunikasi dengan peserta microteaching, belum bisa mengelola kelas dengan baik, kurang mampu menggunakan media pembelajaran, calon pendidik belum mampu memberikan pertanyaan yang memicu peserta didik untuk berfikir tingkat tinggi dan kurang menstimulus peserta didik dalam menyelesaikan permasalahan, kemampuan menjelaskan relatif kurang, dan kurang memotivasi peserta microteaching.

Pentingnya matakuliah Dasar Proses Pembelajaran Biologi bagi calon pendidik, maka kegiatan perkuliahan harus sesuai dengan tujuan dan indikator keterampilan kompetensi. Berdasarkan hasil analisis SAP oleh peneliti bulan Maret 2013 menunjukkan matakuliah Dasar Proses Pembelajaran BIO memiliki kredit 2 sks dan 3 js ( 3 x 50 menit) selama 16 kali pertemuan dan diharapkan mahasiswa dapat memperoleh keterampilan dalam melakukan proses belajar mengajar biologi secara maksimal melalui perkuliahan yang ditunjang dengan adanya buku ajar (SAP Matakuliah Dasar Proses Pembelajaran Biologi, 2012). Hasil wawancara dengan Dosen pengampu matakuliah Dasar Proses Pembelajaran Biologi IKIP Budi Utomo menunjukkan bahwa perkuliahan dilakukan dengan penyampaian teori dan belum banyak mengangkat kesulitan-kesulitan yang terjadi dalam pembelajaran biologi serta tidak banyak memberdayakan keterampilan mengajar.

Alasan peneliti memilih buku ajar yaitu mengatasi permasalahan yang didapatkan dari hasil observasi di atas. Kelebihan buku ajar antara lain; mampu menstimulasi peserta didik untuk mempelajari materi pembelajaran lebih awal, mampu membantu peserta didik dalam memahami dan menguasai materi pembelajaran, dan mampu mempercepat dalam pencapaian tujuan pembelajaran (Anggela dkk, 2013). Buku ajar yang akan dibuat oleh peneliti dikembangkan dengan mengadaptasi model pengembangan Thiagarajan (1974) yang mana terdiri atas; tahap pendefinisian (define), perancangan (design), pengembangan (develop), dan penyebarluasan (disseminate). Berdasarkan permasalahan-permasalahan di atas, maka diperlukan penelitian dengan judul "Pengembangan Buku Ajar Keterampilan Dasar Mengajar Berbasis Sains Teknologi Masyarakat Pada Program Studi Pendidikan Biologi IKIP Budi Utomo Malang".

\section{METODE}

Penelitian ini dilaksanakan di kampus IKIP Budi Utomo Malang, mahasiswa Program Studi Pendidikan Biologi yang sedang menempuh matakuliah Dasar Proses Pembelajaran Biologi. Pengumpulan data dalam penelitian ini Uji skala kecil digunakan untuk mengetahui kelayakan Buku Ajar yang telah dikembangkan. Uji coba skala kecil menggunakan 20 mahasiswa Program Studi Pendidikan Biologi IKIP Budi Utomo Malang yang sedang menempuh matakuliah Dasar Proses Pembelajaran Biologi.

Tahap pengembangan buku ajar matakuliah Dasar Proses Pembelajaran Biologi dapat diuraikan sebagai berikut; Tahap pendefinisian (Define), Pada tahap ini dilakukan analisis untuk menentukan tujuan pembelajaran dan batasan materi yang akan dikembangkan. Beberapa analisis yang dilakukan pada tahap ini antara lain:

1. Analisis ujung depan, dilakukan untuk menentukan masalah mendasar yang dihadapi Dosen. Analisis ujung depan dapat dilakukan dengan wawancara dengan dosen dan analisis SAP terkait dengan permasalahan yang menjadi kendala dalam matakuliah Dasar Proses Pembelajaran Biologi.

2. Analisis tugas dan konsep, dilakukan dengan menelaah standar kompetensi dan kompetensi dasar yang digunakan pada matakuliah Dasar Proses Pembelajaran Biologi untuk mengembangkan buku ajar. Analisis ini dapat dilakukan dengan menganalisis silabus atau SAP (Satuan Acara Perkuliahan) matakuliah Dasar Proses Pembelajaran sehingga mengetahui kompetensi dasar yang harus dikuasai oleh mahasiswa. 
3. Analisis tujuan, dilakukan dengan mengidentifikasi dan menentukan ruang lingkup unit materi yang harus dikuasai. Analisis tujuan digunakan untuk menentukanjumlah dan judul bahan, materi atau konsep utama yang harus tertuang dalam buku ajar yang dikembangkan untuk mencapai kompetensi tersebut. d) Identifikasi sumber pustaka dan menganalisis kekurangan dari sumber pustaka yang digunakan pada matakuliah Dasar Proses Pembelajaran Biologi.

Tahapan untuk pengembangan dijelaskan sebagai berikut; a) Validasi, validasi buku ajar dilakukan melalui tiga tahap validasi sebagai berikut. b) Validasi oleh Validator Ahli Materi Pembelajaran Biologi dengan kriteria: dosen yang memiliki pengalaman mengajar matakuliah PBM BIO dan menguasai materi keterampilan dasar mengajar, serta memiliki kualifikasi pendidikan minimal S2; 1) Validasi oleh Validator Ahli Media Pembelajaran dengan kriteria: dosen yang memiliki kemampuan di bidang Media Pembelajaran dan memiliki kualifikasi pendidikan minimal S2. 2) Validasi oleh praktisi dengan kriteria: dosen yang memiliki pengalaman mengajar matakuliah PBM BIO di Program Studi Pendidikan Biologi IKIP Budi Utomo. 3) Uji Skala kecil (kelompok kecil), uji skala kecil digunakan untuk mengetahui kelayakan dan keterbacaan dari buku ajar yang telah dikembangkan. Uji coba skala kecil menggunakan 20 mahasiswa Program Studi Pendidikan Biologi IKIP Budi Utomo Malang yang sedang menempuh matakuliah Dasar Proses Pembelajaran Biologi. 4) Revisi, merupakan suatu proses penyempurnaan buku ajar setelah memperoleh masukan dari kegiatan validasi dan uji coba skala kecil. Beberapa kekurangan yang diketahui berdasarka hasil dari kegiatan validasi dan uji coba skala kecil tersebut, selanjutnya dijadikan masukan dalam memperbaiki buku ajar.

\section{HASIL}

Hasil beberapa validasi oleh ahli pendidikan dapat dijelaskan seperti Tabel di bawah ini.

\begin{tabular}{|c|l|c|}
\hline No & \multicolumn{1}{|c|}{ Indikator } & Kriteria \\
\hline 1 & Bab I Pendahuluan & Cukup Valid \\
\hline 2 & Bab II Keterampilan Membuka dan Menutup & Cukup Valid \\
\hline 3 & Bab III Keterampilan Menjelaskan & Cukup Valid \\
\hline 4 & Bab IV Keterampilan Mengadakan Variasi & Cukup Valid \\
\hline 5 & Bab V Keterampilan Mengelola Kelas & Cukup Valid \\
\hline 6 & Bab VI Keterampilan Mengajar Kelompok Kecil dan Perorangan & Cukup Valid \\
\hline 7 & Bab VII Keterampilan Memimpin Diskusi Kelompok Kecil & Cukup Valid \\
\hline 8 & Bab VIII Keterampilan Bertanya & Cukup Valid \\
\hline 9 & Bab IX Keterampilan Memberi Penguatan & Cukup Valid \\
\hline 10 & Bab X Keterampilan Membuat RPP & Cukup Valid \\
\hline
\end{tabular}

Hasil Validasi oleh Validator Ahli Media Pembelajaran

\begin{tabular}{|c|l|c|}
\hline No & \multicolumn{1}{|c|}{ Aspek yang dinilai } & Kriteria \\
\hline 1 & Ukuran Buku & Valid \\
\hline 2 & Desain Buku Sampul & Cukup Valid \\
\hline 3 & Tipografi Sampul Buku & Valid \\
\hline 4 & Ilustrasi Buku & Cukup Valid \\
\hline 5 & Desain Isi Buku & Valid \\
\hline 6 & Tipografi Isi Buku & Valid \\
\hline
\end{tabular}

Hasil Validasi oleh Validator Praktisi

\begin{tabular}{|c|l|c|}
\hline No & \multicolumn{1}{|c|}{ Aspek yang dinilai } & Kriteria \\
\hline 1 & $\begin{array}{l}\text { Kesesuaian waktu yang tersedia dalam pembelajaran dengan } \\
\text { penggunaan buku ajar. }\end{array}$ & Valid \\
\hline 2 & $\begin{array}{l}\text { Kemampuan buku ajar sebagai alat bentu pencapaian indikator/tujuan } \\
\text { pembelajaran. }\end{array}$ & Valid \\
\hline
\end{tabular}


146 | As'ad Syamsul Arifin, Pengembangan Buku Ajar Keterampilan ...

\begin{tabular}{|c|l|c|}
\hline No & \multicolumn{1}{|c|}{ Aspek yang dinilai } & Kriteria \\
\hline 3 & $\begin{array}{l}\text { Ketertarikan mahasiswa ketika belajar dengan memanfaatkan buku } \\
\text { ajar yang telah dikembangkan. }\end{array}$ & Valid \\
\hline 4 & $\begin{array}{l}\text { Kemampuan buku ajar dalam menciptakan rasa senang pada } \\
\text { mahasiswa. }\end{array}$ & Valid \\
\hline 5 & Kemampuan buku ajar untuk dapat digunakan secara berulang-ulang. & Cukup Valid \\
\hline 6 & $\begin{array}{l}\text { Kemampuan buku ajar dalam menciptakan motivasi belajar } \\
\text { mahasiswa. }\end{array}$ & Cukup Valid \\
\hline 7 & $\begin{array}{l}\text { Kemampuan buku ajar dalam membantu mahasiswa memahami } \\
\text { informasi. }\end{array}$ & Valid \\
\hline 8 & \begin{tabular}{l} 
Kemampuan buku ajar dalam memicu kreativitas mahasiswa. \\
\hline 9
\end{tabular} & $\begin{array}{l}\text { Kemampuan buku ajar untuk mengaktifkan mahasiswa dalam } \\
\text { membangun pengetahuan sendiri. }\end{array}$ \\
\hline 10 & $\begin{array}{l}\text { Kesesuaian buku ajar dengan dunia mahasiswa yang sedang diajar. } \\
\text { Valid }\end{array}$ \\
\hline
\end{tabular}

Hasil Tanggapan Mahasiswa saat Uji Coba Skala Kecil

\begin{tabular}{|c|l|c|}
\hline No & \multicolumn{1}{|c|}{ Aspek yang dinilai } & Kriteria \\
\hline 1 & Identitas buku ajar ini cukup jelas & Valid \\
\hline 2 & Kompetensi dasar dan indikator pada tiap bab jelas & Valid \\
\hline 3 & Bahasa yang digunakan dalam buku ajar cukup jelas & Valid \\
\hline 4 & Materi dalam buku ajar runtut & Valid \\
\hline 5 & Buku ajar memuat keseluruhan kompetensi dasar mengajar & Valid \\
\hline 6 & Soal latihan dalam buku ajar mudah dipahami & Valid \\
\hline 7 & $\begin{array}{l}\text { Bahasa yang digunakan dalam soal latihan pada buku ajar ini mudah } \\
\text { dipahami }\end{array}$ & Valid \\
\hline
\end{tabular}

\section{PEMBAHASAN}

Berdasarkan hasil validasi oleh validator, diantaranya Bab I Pendahuluan, Bab II keterampilan membuka dan munutup, Bab III keterampilan menjelaskan, Bab IV Keterampilan mengadakan variasi, Bab V keterampilan mengelola kelas, Bab VI keterampilan mengajar kelompok kecil dan perorangan, Bab VII keterampilan diskusi kelompok kecil, Bab IX keterampilan memberikan penguatan, Bab X keterampilan membuat RPP. Hasil validator menunjukkan bahwa "Cukup Valid", artinya buku ini layak dipakai oleh tenaga pendidik.

Sama seperti yang dikatakan Djamarah dalam Merry Safitri (2000:31) dalam pengertian sederhana, pendidik adalah orang yang memberikan ilmu pengetahuan kepada anak didik. Dalam PP Nomor 19 Tahun 2005 tentang Standar Nasional Pendidikan dinyatakan bahwa seorang pendidik dituntut memiliki kualifikasi kompetensi pedagogik, kepribadian, profesional, dan sosial. Pernyataan tersebut menyiratkan bahwa pendidik dituntut memilik empat aspek untuk mengarahkan diri sebagai tenaga profesional. Salah satu kompetensi yang berkaitan langsung dengan tugas pendidik mengajar, membimbing, dan mendidik mahasiswa adalah kompetensi pedagogik. Kompetensi ini menuntut kemampuan pendidik dalam mengelola pembelajaran, mulai dari merancang, melaksanakan, sampai dengan mengevaluasi hasil belajar mahasiswa sehingga tujuan pembelajaranpun tercapai.

Turney (dalam Mulyasa, 2005: 69) mengungkapkan delapan keterampilan mengajar yang sangat menentukan kualitas pembelejaran, yaitu (1) keterampilan memberi penguatan, (2) keterampilan bertanya, (3) variasi, (4) menjelaskan, (5) keterampilan membuka dan menutup pelajaran, (6) keterampilan mengelola kelas, (7) mengajar kelompok kecil dan perorangan, dan (8) keterampilan membimbing diskusi kelompok kecil agar pembelajaran dapat berjalan dengan baik, pendidik perlu menguasai keterampilan dalam membimbing diskusi kelompok kecil.

Berdasarkan hasil validasi oleh validator ahli media pembelajaran, Ahli media memberikan kriteria tentang ukuran buku, desain buku sampul, tripografi sampul buku, ilustrasi buku, 
desain isi buku, dan tropografi isi buku, ahli media memberikan nilai "Valid" dan layak dipergunakan, dan mengenai aspek yang lain seperti desain buku sampul dan ilustrasi buku, ahli media memberikan nilai criteria "Cukup Valid". Sehingga pada saat presentasi pertanggung jawaban di kampus IKIP Budi Utomo Malang, pada tanggal 9 Desember, buku ini hanya disarankan menempel logo almamater IKIP Budi Utomo, untuk yang lainnya sudah disetujui.

Hasil validasi oleh validator praktisi menunjukkan bahwa beberapa aspek yang dinilai seperti kesesuaian waktu yang tersedia dalam pembelajaran dengan penggunaan buku ajar, kemampuan buku ajar sebagai alat bentu pencapaian indikator atau tujuan pembelajaran, ketertarikan mahasiswa ketika belajar dengan memanfaatkan buku ajar yang telah dikembangkan, kemampuan buku ajar dalam menciptakan rasa senang pada mahasiswa, kemampuan buku ajar untuk dapat digunakan secara berulang-ulang, kemampuan buku ajar dalam menciptakan motivasi belajar mahasiswa, kemampuan buku ajar dalam membantu mahasiswa memahami informasi, kemampuan buku ajar dalam memicu kreativitas mahasiswa, kemampuan buku ajar untuk mengaktifkan mahasiswa dalam membangun pengetahuan sendiri, dan kesesuaian buku ajar dengan dunia mahasiswa yang sedang diajar. praktisi menilai bahwa aspek ini layak dan memberikan criteria "Valid".

Hasil tanggapan mahasiswa saat uji coba skala kecil ini memberikan suasana yang sangat baik, aspek yang dinilai antara lain identitas buku ajar ini cukup jelas, kompetensi dasar dan indikator pada tiap bab jelas, bahasa yang digunakan dalam buku ajar cukup jelas, materi dalam buku ajar runtut, buku ajar memuat keseluruhan kompetensi dasar mengajar, Soal latihan dalam buku ajar mudah dipahami, bahasa yang digunakan dalam soal latihan pada buku ajar ini mudah dipahami, buku ajar yang saudara pelajari dapat menimbulkan motivasi dalam menguasai kompetensi dasar mengajar, buku ajar yang saudara pelajari dapat menimbulkan kemandirian dalam mempelajarinya, buku ajar yang saudara pelajari mampu mengeksplore saudara untuk meningkatkan kemampuan dasar mengajar, buku ajar yang saudara pelajari mampu meningkatkan kemampuan mengajar dengan mengkaitkan antara materi dengan isu di masyarakat dan teknologi, buku ajar mampu memunculkan permsalahan dan fenomena yang dekat dengan kehidupan sehari-hari untuk mengembangkan kemampuan mengajar, materi di dalam buku ajar relevan mendukung dalam penguasaan kompetensi dasar mengajar, materi didalam bukuajar lengkap dan mudah dipahami, buku ajar dapat meningkatkan keinginan untuk meningkatkan kualitas keterampilan dasar mengajar. Para mahasiswa memberikan Kriteria "Valid", ini menandakan bahwa ketertarikan mahasiswa dalam melaksanakan proses pembelajaran matakuliah Dasar Proses Pembelajaran Biologi menggunakan buku yang telah di validasi.

Telah dijelaskan bahwa Buku ajar adalah informasi tertulis yang digunakan oleh guru dan peserta didik dalam proses belajar mengajar (Anggela dkk, 2013). Manfaat buku ajar antara lain; Peserta didik dapat mempelajari lebih awal bahan kajian atau materi yang akan dibahas pada pembelajaran. Dapat membantu peserta didik dalam memahami materi yang dibahas pada pembelajaran. Mempermudah mencapai tujuan pembelajaran yang diharapkan karena dalam buku ajar memuat materi yang menuntun peserta didik dalam mencapai tujuan pembelajaran yang telah ditetapkan.

Buku ajar secara garis besar merupakan pengetahuan, keterampilan, dansikapyangharus dipelajari peserta didik dalam rangka mencapai standar kompetensi dan kompetensi dasar (Diknas, 2008). Salah satu model pengembangan buku ajar adalah model pengembangan Thiagarajan (1974). Model pengembangan Thiagarajan terdiri atas 4 tahapan, yaitu; pendefinisian (define), perancangan (design), pengembangan (develop), dan penyebarluasan (disseminate).

Tahap pendefinisian, pada tahap ini dilakukan analisis kebutuhan. Tahap perancangan, pada tahap ini dilakukan untuk merumuskan prototipe buku ajar, rancangan pembelajaran dan perangkat pembelajaran. Tahap pengembangan, pada tahap ini dilakukan proses validasi ahli dan praktisi yang dilakukan untuk mengetahui kelayakan buku ajar, dan uji coba untuk mengetahui keterbacaan buku ajar. Tahap penyebarluasan, pada tahap ini dilakukan pengujian buku ajar yang dihasilkan pada pembelajaran Dasar Proses Pembelajaran Biologi.

Matakuliah Dasar Proses Pembelajaran Biologi merupakan matakuliah keilmuan dan keterampilan bidang studi pada program S-1 Program Studi Pendidikan Biologi dengan status matakuliah wajib. Matakuliah ini membahas dasar-dasar proses pembelajaran biologi. Secara garis besar, lingkup bahasan pada matakuliah 
ini mencakup; (1) keterampilan membuka pembelajaran biologi, (2) keterampilan menutup pembelajaran biologi, (3) keterampilan bertanya, menjawab, dan menjelaskan dalam pembelajaran biologi, (4) keterampilan memberi penguatan pada pembelajaran biologi, (5) keterampilan menumbuhkan keantusiasan dan minat siswa, (6) keterampilan memilih metode pembelajaran biologi, (7) keterampilan membuat media pembelajaran biologi, (8) keterampilan melakukan demostrasi dan eksperimen dalam pembelajaran biologi, (9) keterampilan membuat langkah-langkah pembelajaran biologi, (10) keterampilan membuat RPP dalam pembelajaran biologi, dan (11) Simulasi mengajar (modelling) pada pembelajaran biologi.

\section{KESIMPULAN DAN SARAN}

Perkuliahan Dasar Proses Pembelajaran Biologi Program Studi Pendidikan Biologi IKIP Budi Utomo Malang dapat memfasilitasi para calon guru yang memiliki kompetensi profesional dan pedagogik. Menghasilkan buku ajar dasar proses pembelajaran Biologi Program Studi pendidikan Biologi yang layak untuk dipergunakan dalam perkuliahan. Selain itu dalam aspek yang telah di validasi oleh tim ahli antara lain terkait dengan mataeri pendidikan telah disepakati "Valid", kemudian media pembelajaran telah disepakati "Valid", hasil validator praktisi telah disepakati "Valid" dan tanggapan uji coba sekala kecil oleh mahasiswa telah disepakati "Valid.

Pengembanganbukuajar keterampilan dasar mengajar berbasis sains teknologi masyarakat pada program studi pendidikan biologi IKIP Budi Utomo Malang telah dikembangkan dapat digunakan dalam proses perkuliahan dasar proses pembelajaran biologi. Penelitian ini masih jauh dari kesempurnaan, maka dari itu kritik dan saran tetap kami tunggu dan akan kami perbaiki. Penelitian ini juga masih bisa ditindak lanjuti mengenai penelitian tanggapan mahasiswa dengan uji sekala kecil yang lainnya yang terkait dengan materi ajar guna meningkatkan kualitas calon guru di masa depan.

\section{DAFTAR RUJUKAN}

Anggela, M., Masril, Darvina, Y. Pengembangan Buku Ajar Bermuatan Nilai-Nilai Karakter pada Materi Usaha dan Momemtum untuk Pembelajaran Fisika Siswa Kelas XI SMA (Jurnal Vol. 1, 63-70). Pandang: Universita Negeri Pandang.

Djamarah, Syaiful Bahri. 2000. Guru dan Anak Didik Dalam Interaksi Edukatif. Jakarta: PT. Rineka Cipta

Mulyasa, E. (2009). Menjadi Guru Profesional Menciptakan pembelajaran Kreatif dan Menyenangkan. Bandung: Rosda.

Muslim Banun Sri. (2010). Supervisi Pendidikan Meningkatkan KualitasProfesionalisme Guru. Bandung: Alfabeta.

Katalog Jurusan Biologi Biologi IKIP Budi Utomo Malang. 2012. Malang.

Kurikulum Program Studi Pendidikan Biologi FPIEK IKIP Budi Utomo. 2009. Malang.

Thiagarajan. 1974. Instructional Development for Training Teachers of Exceptional Children. University of Minnesota. 